\title{
Using Critical Environmental Agency to Engage Teachers in Local Watersheds through Water Quality Citizen Science
}

\author{
Lacey D. Huffling * and Heather C. Scott
}

check for

updates

Citation: Huffling, L.D.; Scott, H.C.

Using Critical Environmental Agency

to Engage Teachers in Local

Watersheds through Water Quality

Citizen Science. Water 2021, 13, 205.

https: / doi.org/10.3390/w13020205

Received: 1 December 2020

Accepted: 14 January 2021

Published: 16 January 2021

Publisher's Note: MDPI stays neutral with regard to jurisdictional clai$\mathrm{ms}$ in published maps and institutional affiliations.

Copyright: (C) 2021 by the authors. Licensee MDPI, Basel, Switzerland. This article is an open access article distributed under the terms and conditions of the Creative Commons Attribution (CC BY) license (https:// creativecommons.org/licenses/by/ $4.0 /)$.
Department of Middle Grades and Secondary Education, Georgia Southern University, Statesboro, GA 30460, USA; hscott@georgiasouthern.com

* Correspondence: lhuffling@georgiasouthern.com

\begin{abstract}
This qualitative study explores teachers' critical environmental agency (CEA) through deepening content knowledge, engaging in identity development, developing a critical consciousness of place, and moving toward civic action. We explored the meanings secondary science teachers made of an on-going professional development (PD) situated in the Okefenokee Swamp (unique ecosystem that drains to Gulf of Mexico and Atlantic Ocean) and focused on local watershed citizen science monitoring and the global implications of all water being connected. Data analyses focused on how the nineteen teachers' experiences and meanings were leveraged to develop CEA and the constraints that restricted their CEA development. Our findings broaden the understanding of how teachers, who teach historically underrepresented youth in low socioeconomic rural areas, come to see themselves as people who care about the environment and become empowered to envision a more sustainable future for their students and communities.
\end{abstract}

Keywords: environmental education; agency; identity; place; environmental literacy; water quality; citizen science

\section{Introduction}

"The perspective of the water quality as the focus of this workshop, it is so critical for all of them [students] to have that knowledge, to enrich their lives with that knowledge, to share the importance of watersheds and healthy water quality given water is the molecule of life" (PD Participant, 2019).

When educators create focused learning opportunities that bridge students' local communities with real-world issues involving water quality, students develop a relationship with water, as awareness is raised for water problems at the local, national, and global levels and promoting action towards better water use [1]. Water's value is increasing almost daily, and therefore the need to create water-literate students is urgent. By high school, students have already developed their water responsibility [2]. This relationship with water is vital as anthropogenic activities account for most of the detrimental changes watersheds around the world are facing [3]. With rapid decreases in global biodiversity, the Earth's environmental health is being severely compromised [4]. Compounded with this, historically underrepresented non-dominant groups in the United States are experiencing a lack of access to environmental education (EE) and science education [5,6]. In particular, middle and high school students from non-dominant groups and rural school systems have limited access to local, place-orientated EE and science experiences in our state given science teacher and resource shortages. Since EE can make place explicit, students, who have more ready access to community-focused EE, are afforded more opportunities to make decisions about and act on local environmental issues, such as water quality, as they learn about the environment in their own community. Therefore, there is an imbalance of equity and access in terms of which student populations are provided opportunities to learn about and engage in their local watersheds and develop their science and environmental literacy. Yet, research indicates that students' attitudes and behavior toward 
water conservation is enhanced through outdoor activities [7], which could lead to further science and environmental literacy development.

Most traditional views of science literacy promote students' enculturation into the practices of science and limits students' ability to leverage their own funds of knowledge and experiences [8]. Yet, youths' lives are engrained in science. Whether it is deciding what to wear or choosing what app to purchase, youth use scientific information to make decisions even if they are not explicitly cognizant of that fact. In fact, scholars have shown that youth are more engaged when science is shown to be relevant to their lives [9-11]. Thus, students' experiences can be situated within science, and critical science literacy envisions such a goal by moving "beyond monolithic narratives of school science and math to incorporate how individuals in their everyday lives appropriate scientific ideas and thinking, and to merge them with other understandings, personal knowledge, and practical experiences" [12] (p. 40). Similar to the other two perspectives of scientific literacy (Vision I concentrates on knowledge and skill acquisition while Vision II adds social and cultural aspects to Vision I) [13,14], critical science literacy still supports the development of knowledge, practices, and skills. Yet, it entails: (1) transformation of spaces where students learn and do science, (2) transformation of the discourses and practices of science and classrooms, and (3) transformations of students' identities [12].

Citizen science (public participation in scientific data collection [15]) offers a unique opportunity for teachers to engage students' critical science literacy development as investigations are situated on school grounds or in local communities. Citizen science transforms where students do and learn science. There is also the possibility of citizen science impacting the science practices used and developed in classrooms [16], and when teachers engage students in citizen science projects, students can envision themselves as capable of doing science [17], which leads to identity development. Furthermore, pairing citizen science opportunities with planned educational experiences in formal educational settings can benefit students' and teachers' experiences [18] and science literacy development [19].

\subsection{Critical Science Agency}

Leveraging students' citizen science experiences through robust and meaningful science learning and identity development can in turn lead to critical science agency (CSA). CSA "implies that students: (a) gain a deep understanding of science and the processes, skills and modes of inquiry associated with the content of science; (b) identify themselves as experts in one or more realms associated with the content of science; (c) and use science as a foundation for change, such that their identity develops, their position in the world advances, and/or they alter the world towards what they envision as more just" [5] (p. 6). Science equity scholars have explored how students exhibit CSA through their science participation and science identity development, thus affording scholars the ability to better understand how students attempt to use their own lived experiences in service of science learning [10,20-23].

Though researchers have used place to further their understanding of CSA, it is not a central principle of CSA. However, EE scholars have discussed how place might motivate people to become more knowledgeable about the environment, which may lead to changes in disposition and actions. As there are many different definitions among scholars from various disciplines (e.g., geography, EE, and outdoor education) who conduct place research [24], we define place as a space that includes "its physical, biological, ecological, and cultural features" [25] (p. 38). Place-based education has been shown to encourage the use of schoolyards, communities, and local greenspaces, and it aids in fostering students connections to nature and their communities [26]. Place-based education also supports environmental awareness [24,27], provides equitable opportunities for students [9], and encourages connectedness to nature $[28,29]$. 


\subsection{Environmental Literacy}

Environmental literacy is similar to scientific literacy in that it promotes knowledge and understanding of environmental concepts, as well as skills and practices associated with the environmental sciences. Yet, as Carter and Simmons observe, "environmental literacy requires knowledge and skills that both build upon and go beyond the environmental sciences" [30] (p. 13). Thus, environmental literacy goes beyond scientific literacy and includes knowledge from other disciplines (such as economics, political science, and history) as well as addresses affective dispositions and behavioral choices [31].

In regard to conceptual understanding and disposition shifts, both formal and informal EE programs have been shown to influence these parameters [32-35]. Scholars have also researched instructional approaches, such as environmental action research and environmental service learning, to better understand how they aid in youths' participation in environmental issues and decision making [36-41]. Considering identity development from a critically-oriented sociocultural perspective offers a needed lens for researching environmental literacy development. Students' ability to position themselves and how they are positioned in relation to the subject matter, practices, and cultural norms offers new insights.

Furthermore, a critical consciousness of place can lead to further environmental literacy development by helping students learn to recognize environmental destruction and disruption (decolonization) and then applying this newfound awareness to learn to live socially and ecologically responsibly in these places (reinhabitation) [42]. Greenwood develops three questions to consider- "a. What happened here? (historical); b. What is happening here now and in what direction is this place headed? (sociocultural); c. What should happen here? (ethical)" [42] (p. 97)—in order to focus on the historical, sociocultural, and ethical dimensions of the place. The focus on decolonization and reinhabitation allows researchers to address both individual and collective views of place, and it acknowledges that even if individuals bring with them previous experiences, conversations and interactions with others, which influences their attachment and meanings. Thus, a critical consciousness of place should lead to further development of one's sense of place as one discovers the historical background of place, considers the socioecological aspects of the place, and ponders the ethical dimensions of coming to know the place.

\subsection{Theoretical Framework}

Building upon CSA and environmental literacy research, we implemented a critical environmental agency (CEA) framework [43] (Figure 1). CEA is predicated upon two overarching ideas: (1) that peoples' lives belong in EE, thus broadening its practices and (2) EE enriches peoples' lives by empowering them with knowledge and skills that lead them to opportunities for CEA development (see Figure 1). CEA implies that people will:

(a) Gain a deeper understanding of the sciences that inform environmental education (EE) and the processes, skills, and modes of inquiry associated with the sciences [5,10];

(b) Identify themselves as experts in one or more realms associated with EE (such as environmental sciences, economics, and political sciences) [5,10];

(c) Gain a deep understanding of place, eventually leading to a critical consciousness of place [42];

(d) Strengthen their sense of place and demonstrate behaviors, actions, and/or individual and/or collective agency to consider, discuss and/or act on environmental issues [44];

(e) Use EE as a foundation for change, such that their identity develops, their position in the world advances, and/or they alter the world towards what they envision as more just $[5,10]$. 


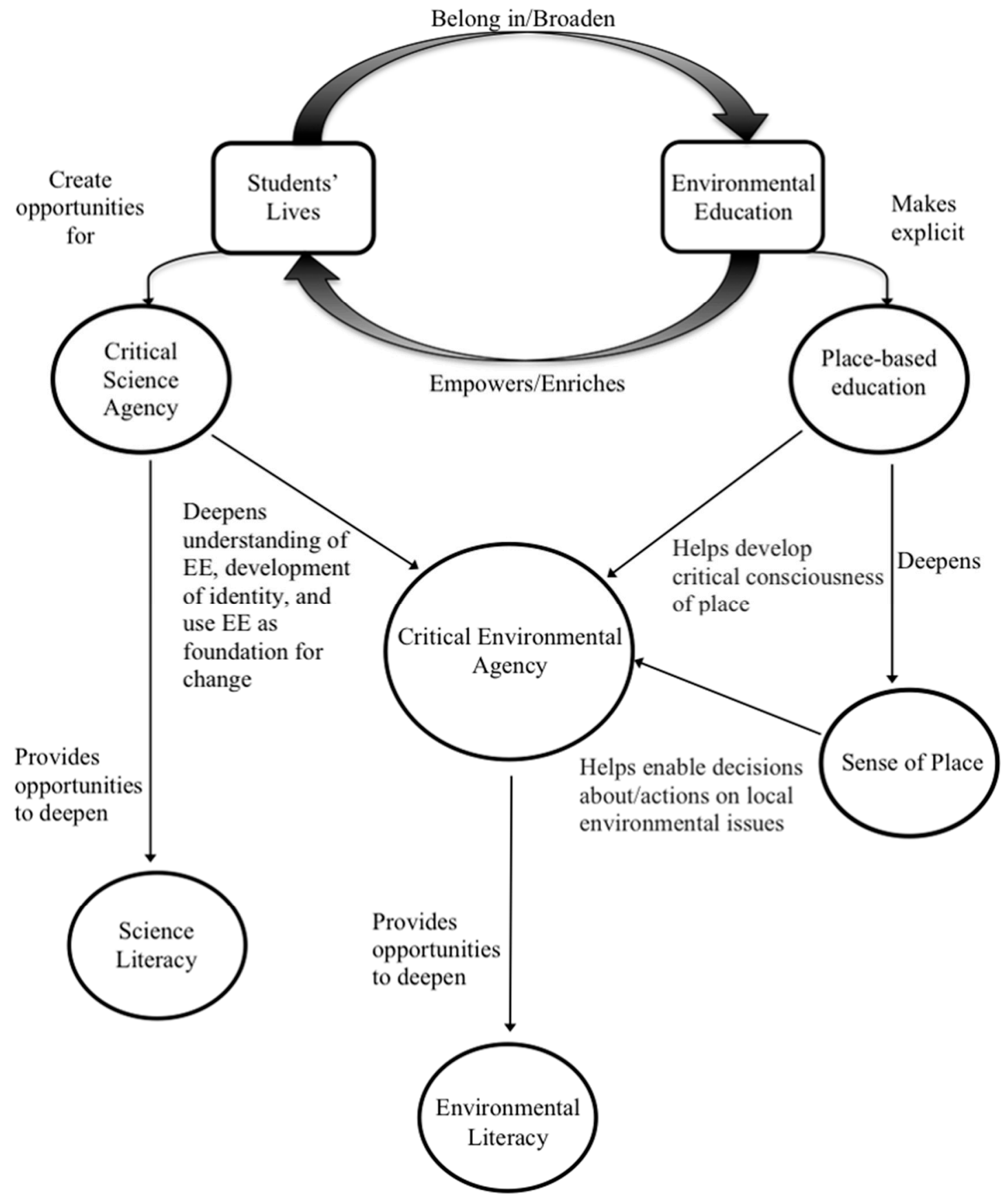

Figure 1. Conceptual framework for critical environmental agency.

\subsection{Purpose of Study}

Given our use of CEA, we designed our study to examine middle and high school science teachers' engagement and perceptions of a professional development (PD) focused on the global implications of all water being connected through the implementation of our state's citizen science water monitoring program (Adopt-A-Stream) with a particular emphasis on the teachers' local watersheds and school yards. An additional goal of this study was to expand and broaden the understanding of how teachers, who teach historically underrepresented youth in low socioeconomic rural areas in our state, come to see themselves as people who care about their watersheds and are resolved to help create a more just world for their students and their communities. Thus, the research question we addressed was: 
How was participants' critical environmental agency enabled or constrained during a PD focused on water quality citizen science?

\section{Methods}

\subsection{Study Design}

Our qualitative study embraces an interpretivistic tradition, which assumed that participant meanings and understanding were developed socially and experientially $[45,46]$. Adhering to this, we designed the PD program using the CEA framework to create an experiential setting for our participants to engage and expand their CEA (Table 1). As researchers, we attempted to understand the learning experiences from the viewpoint of our participants [47]. In this regard, we used data collection instruments such as interviews, content assessments, watershed mapping, field notes, and open-ended survey questions to capture our participants' meanings.

Table 1. CEA principles and examples of how PD was designed.

\section{CEA Principle Definition}

Examples of How Designed for PD

Adopt-a-Stream training; ArcGIS; content lectures;

DataClassroom; Deep Water Horizon movie; field trips into the Swamp; Flatbirds; Frogging; Model My Watershed; NSTA Learning Center; Phenology; Soil Your Undies; StreamStats; StoryMaps Tall Timbers Fire Ecology and Foodweb; TriState Water PBL; USGS

Knowledge: gain a deep understanding of the sciences that inform environmental education (EE) and the processes, skills, and modes of inquiry associated with the sciences

Identity: identify themselves as experts in one or more realms associated with EE (such as environmental sciences, economics, and political sciences)
Collaborative discussions and sharing out each evening; macroinvertebrate identification practice; Phenology Scavenger

Hunt; photovoice assignment; Okefenokee Escaperoom; Schoolyard Final Project

Travel to the three entrances of the Okefenokee to see the differences (boat tours, boardwalks, etc.); use of local consultants/guides; photovoice assignment; watershed mapping; Schoolyard Final Project

Collaborative brainstorming sessions for schoolyard project designs; photovoice presentation; Schoolyard Final Project Presentation

Community focused citizen science projects; Schoolyard Final Project Presentation

\subsection{Study Context}

This study resulted from the first year of our grant-funded PD opportunity-Okefenokee -Understanding Real-World Relevance through Suwannee Watershed Assessment and Monitoring Project (Our ${ }^{2}$ Swamp). The purpose of Our ${ }^{2}$ Swamp is to create a new hands-on research-based PD designed to monitor local watershed conditions and examine impacts on the Gulf of Mexico. The primary content focus was on the health and resilience of the Okefenokee Swamp and participants' local watersheds. Participants were equipped to integrate local watershed health monitoring (through Adopt-A-Stream and other citizen science projects) to increase students' understanding of causal relationships and the impact of local watersheds on larger water bodies. The project team included two science and environmental educators (authors), a biology professor, a chemistry professor, and two consultants who had led multiple groups into the Okefenokee Swamp.

As part of the PD, participants attended one of four preview PD days offered in the spring of 2019. The preview day was designed to introduce the participants to their watershed and how our state impacts two coastal areas. Preview days were planned and hosted at different sites around the state to accommodate participants and minimize their 
travel time. Preview days were also designed to introduce participants to some of the technology they would work with over the week-long summer workshop. Participants were also given a photovoice homework assignment to complete prior to the week-long summer PD based on the SHOWeD protocol that multiple photovoice researchers have used [48,49].

In June 2019, participants traveled to and attended a week-long PD in our state's largest swamp, which is designated a National Wildlife Refuge. The Okefenokee Swamp is located on the Georgia Florida border. This over 400,000 acre wetland serves as the headwaters for the St. Mary's River and the Suwannee River, positioning it in a unique situation as it drains to both the Atlantic Ocean and the Gulf of Mexico (Figure 2). During the week, participants stayed on site, where they were trained and certified to develop their own water chemical testing, bacterial testing, and macroinvertebrate survey sites for our state Adopt-A-Stream water monitoring database. They were also introduced to other citizen science projects such as birding through eBird, tree and bird phenology through Nature's Notebook, and the leaf pack network from Stroud Water Center.

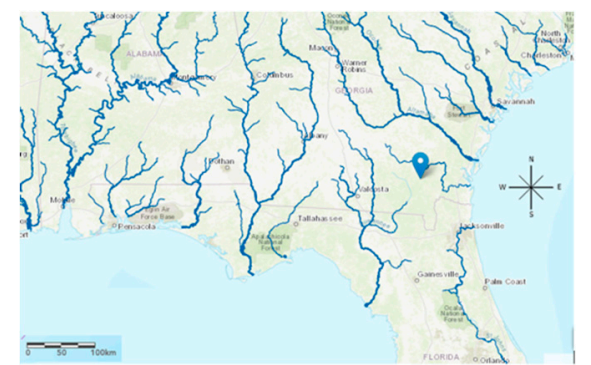

(a)

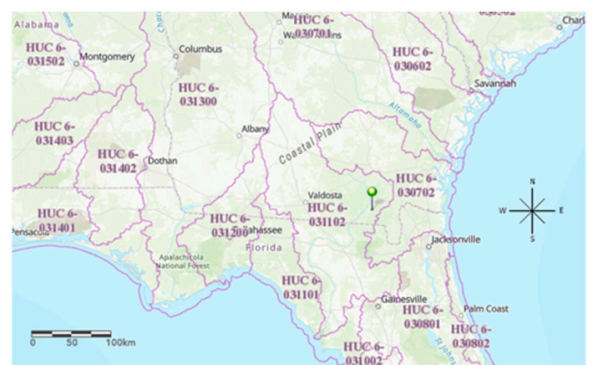

(b)

Figure 2. (a) Major rivers around the Okefenokee Swamp (blue pin). Map created using Model My Watershed program with Continental US Medium Resolution Stream Network overlay; (b) HUC-6 watersheds around the Okefenokee Swamp (blue pin). Map created with ArcGIS, USGS Watershed Overlay.

\subsection{Participants}

Participants were selected based upon an application process, as we had more participants interested than we had spots available due to lodging and funding limitations. The application was shared with the state science education listserv and with our target areas through their respective state regional education office. Applicants were scored using a rubric developed by our project team in order to give preference to applicants who met the demographics supported by our grant funding agency. Preference was given to participants who taught in areas with historically underrepresented student populations with regard to access to science, were unrepresented in the Adopt-A-Stream water monitoring database in our state, and/or were in districts with watersheds that drained into the Gulf of Mexico. Three project team members separately scored the applicants. Individual composite scores were generated and averaged across the three project team members to produce an overall participant score. The highest-scoring participants were invited to attend the PD $(n=20)$. Twenty participants completed the summer 2019 week-long PD on location in the Okefenokee Swamp (Table 2); however, one participant transitioned into district administration prior to the start of the PD and was not included in the research portion of our PD. Of our 19 participants, 17 taught in rural school districts, with only two teaching in urban areas. Four participants taught grades 6-8, while the rest taught grades 9-12. In regard to subjects taught, participants had taught Earth Sciences $(n=2)$, Environmental Sciences $(n=12)$, Life Sciences $(n=15)$, and Physical Sciences $(n=7)$. Four had also taught courses designated gifted, while two had taught special education science courses. All participants gave their informed consent for inclusion before they participated in this study. This study was conducted in accordance with the Declaration of Helsinki, and the protocol was approved by the IRB Committee of Georgia Southern University (H19045). 
Table 2. Participant demographics.

\begin{tabular}{cccccccc}
\hline \multicolumn{2}{c}{ Gender } & \multicolumn{2}{c}{ Race } & \multicolumn{2}{c}{ Ethnicity } & \multicolumn{2}{c}{ Level of Education } \\
\hline Male & Female & Black/African American & White & Hispanic/Latinx & Bachelors & Masters & Doctoral \\
\hline 3 & 16 & 2 & 17 & 2 & 6 & 12 & 1 \\
\hline
\end{tabular}

\subsection{Data Collection}

Pre-assessment data collection occurred during the spring PD day, where participants completed a science content pre-assessment and a watershed mapping pre-assessment. We also video recorded each of the spring PD days. After the spring preview, participants filled out the teacher environmental literacy [50] pre-survey. During the week-long PD in the swamp, we made observations of participants and kept brief field notes for each day. At the end of the week, we audio recorded individual semi-structured interviews, which were approximately $35-45 \mathrm{~min}$ long. The first part had twelve questions designed to better understand how participants described themselves in regard to their experiences in the PD and how they envision the experience impacting their teaching practices. Part two was a card sort activity that had three questions, which asked participants to assess the practices and design of the PD. Each interview was then transcribed. We also re-administered the science content assessment and a watershed mapping assessment. Participants completed the teacher environmental literacy survey after the PD.

\subsection{Data Analysis}

We used Dedoose to code and analyze our transcribed interview data. For our first round of coding, we used a priori codes based upon the five tenets of CEA: Knowledge, identity, place, action, and vision (Table 3). We analyzed the interviews and environmental literacy survey for affordances the PD offered for CEA development [51]. We also coded for constraints participants shared that they either were able to overcome or felt were still a possible issue. Each researcher individually coded the interviews; then, we examined any codes that were not aligned and reconciled our coding as part of our triangulation efforts. In addition, we used the pre/post-content assessment results to triangulate the code for knowledge. The teacher environmental literacy survey [50] was used to triangulate the code for identity, and the pre/post-watershed map results were used to triangulate the code for knowledge and place. The content assessment and watershed map were scored by our external evaluator using the answer keys. A raw score was generated for each participant based upon the number of correct answers. Paired samples $t$-test were conducted to compare the raw scores on the content assessment and the watershed map before the PD and after the PD. Percentage of positive responses of the identity related questions on the teacher environmental literacy survey were also calculated for the preand post-surveys. Dedoose enabled data visualization through frequency counts, code co-occurrence, code application, and code presence. This enabled us to perform member checks and crystallization of our analysis [52]. Next, we collapsed the a priori codes into emergent themes that captured participant meaning of the CEA principles [53].

Table 3. Data coding chart.

\begin{tabular}{ccc}
\hline Code & Coding Definition & Data Sources Analyzed \\
\hline Knowledge & $\begin{array}{c}\text { Discuss content in the interview (content topics to enhance their } \\
\text { answers), i.e., sensitivity of macros; how they will use with their classes }\end{array}$ & $\begin{array}{c}\text { Adopt-a-Stream Tests, Individual } \\
\text { Interviews; Pre/Post-Science Content } \\
\text { Assessment; Pre/Post-Watershed } \\
\text { Mapping Assessment }\end{array}$ \\
\hline Identity & $\begin{array}{c}\text { Learn enough content that they can share with teachers at their school; } \\
\text { mention other people (or get mentioned); feel smart or proud; defining } \\
\text { themselves; felt "sciency" }\end{array}$ & $\begin{array}{c}\text { Pre/Post-Teacher Environmental Literacy } \\
\text { Survey; Individual Interviews }\end{array}$ \\
\hline
\end{tabular}


Table 3. Cont.

\begin{tabular}{ccc}
\hline Code & Coding Definition & Data Sources Analyzed \\
\hline Place & $\begin{array}{c}\text { Recognize that displacement has occurred; how to bring back } \\
\text { association with a particular place (reinhabit); realizing that there is } \\
\text { habitat that becomes realized as important and valuable; awareness of } \\
\text { environment and communities; understanding where you are without } \\
\text { belonging there }\end{array}$ & Individual Interviews \\
\hline Action & $\begin{array}{c}\text { Demonstrate behaviors, actions, agency is the focus; gain content } \\
\text { knowledge, identifying self as being able to contribute, then take action }\end{array}$ & $\begin{array}{c}\text { Pre/Post-Teacher Environmental Literacy } \\
\text { Survey; Individual Interviews }\end{array}$ \\
\hline Vision & $\begin{array}{c}\text { Envision a change somehow for the place or themselves; may become a } \\
\text { birder; classify yourself in a new way; alter world as more just-for } \\
\text { example, picking up trash that they have become aware of }\end{array}$ & Individual Interviews \\
\hline Constraint & $\begin{array}{c}\text { Discuss examples of times when could not fully engage or did felt } \\
\text { understood aspects of PD }\end{array}$ & Individual Interviews \\
\hline
\end{tabular}

\section{Results}

Our results indicated that the curriculum we developed afforded multiple opportunities for CEA development as participants shared their perspectives of the experiences; yet, there were also external and internal constraints that limited CEA development.

\subsection{Critical Environmental Agency Affordances}

In designing our program, we purposefully created and implemented experiences which would encourage participants' CEA development. Our goal was to model for our participants experiences and activities they could in turn do with students to cultivate CEA. Our coding revealed that participants' meanings did align with our goals of CEA integration as all five principles were coded across 18 of our 19 participants. One individual did not have a code for principle e (vision), and in reflecting upon this individual, we realized she was the most disengaged of the group and, during discussions and even her interview, she discussed how hard and overwhelming the PD was. In pulling apart the principles, we were concerned as to whether we would be able to capture CEA development as we realize that the principles work in conjunction with each other and are not isolated points in time. Thus, we were encouraged when coding that most excerpts were coded for more than one CEA principle, which confirmed that the principles supported each other.

\subsubsection{Principle A: Knowledge}

All 19 participants discussed knowledge they gained during the spring preview and week-long PD. This not only included content in biology, chemistry, environmental sciences, and geography, but participants also identified skills such as observation and data collection. One participant shared how she appreciated a PD that taught science content, "But a lot of our PD is, let me tell you how to work through labs. ADI is big right now. It's just a way to work through a lab. You have argument-driven inquiry. And it's all fine, but I need information. I need someone to talk to me about nitrogen fixation. I need more details on my science. So I feel that I got satisfied in my knowledge". Another participant observed, "We were making new discoveries. We were using the scientific method. We were asking questions, making observations, formulating a hypothesis, setting up some type of experiment. Like when we were listening, we could hear the frog calls, and we were trying to find them".

In addition to participants discussing the deeper understanding they developed, there was a positive significant difference in the scores from the pre-science content assessment $(\mathrm{M}=59.3, \mathrm{SD}=18.87)$ and the post-assessment $(\mathrm{M}=90, \mathrm{SD}=4.60) ; \mathrm{t}(38)=-7.07, p=0.000$ and on scores from the pre-watershed mapping assessment $(\mathrm{M}=35.3, \mathrm{SD}=24.78)$ and the post-assessment $(\mathrm{M}=88.5, \mathrm{SD}=12.78) ; \mathrm{t}(38)=-8.53, p=0.000$. The watershed mapping assessment also highlighted participants' desires to learn about their own watershed 
independently as we did not explicitly teach about each watershed. Rather, we used the Okefenokee as a model for how to learn about a watershed and how to develop a watershed citizen science project. In further analyzing the excerpts coded for knowledge, three themes emerged: knowledge of watersheds, identification skills, and Adopt-A-Stream inquiry practices (Figure 3).

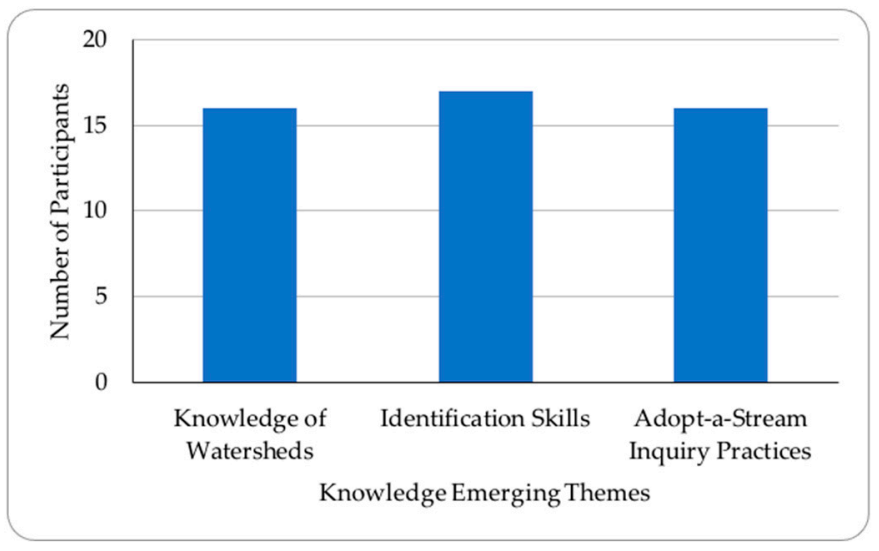

Figure 3. The frequency of emerging themes for the code knowledge.

In regard to knowledge of watersheds, participants noted how the spring preview set the stage for learning about watersheds, while the use of local swamp guides and Adopt-A-Stream training and monitoring solidified their understanding of the importance of watersheds. One participant noted how his view of water had been altered by the knowledge he gained, "The way that water actually travels around is-really, I never thought about it. It's water. Just there. I wasn't sure of where it actually went and it's cool to actually look at that. I really just want to know where it goes. But I want to go find actual bodies of water and streams and see where they're actually at and what leads to it. Because I know we have a lot of farms and the chicken plant and all the chicken farms and things. So it would be cool to see actually what we are contributing". Another participant also discussed how she came to think about local watersheds, "I don't think people realize the impact of what they throw into the water, what they put into the water, and even on a local scale what it does. What it does on a community scale, what it does on the watershed scale, and then eventually, the watersheds eventually do flow into the Gulf where I'm at. And if we're already looking at dead zones, how is the nitrogen runoff, or how is the trash that you throw into the river, how is that going to impact the dead zone, which is actually growing this year? How much more is it going to impact it?".

Identification skills were also continually mentioned as an important part of their experience (Figure 3), especially in terms of the macroinvertebrate surveys and how this reflected water quality. As one participant shared, "I never realized how much 'a bug' can tell me about the quality of the water that's around me, just because of how some are sensitive to pollution and some are tolerant". Several participants noted how identifying organisms was new to them, and they highlighted the birds, trees, frogs, and macroinvertebrates we encountered. One participant summarized her experience with species identification by stating, "That's kind of new to me. I was not comfortable with those before. But now I am. So as far as learning how to identify, and now how to use those in the watershed, knowing how important they are. That was new". Even one of our seasoned participants who has taught over 20 years and has led macroinvertebrate lessons in her class notes how her knowledge had increased when asked about a wow moment during the PD, "the macro-vertebrate identification, I had tried different activities in my classroom along those same lines. I have a file folder with 10 different ID things through the years, but I never have felt like I had enough expertise identifying. So that was just so exciting to refine my skills on that. And because that particular activity is something that kids really get excited about looking at insects like that is primo. So I loved that". 
Adopt-A-Stream monitoring (water chemistry, macroinvertebrates, and Escherichia coli) also afforded opportunities for participants to deepen their understanding of water and watersheds (Figure 3). One participant, who shared she was "not a chemistry person" observed that "having the support of learning the water quality gives me some assurance that when I go back I have better tools to offer the students, I have a little more-a lot more knowledge to take that back and I feel a little more stable in that area". Participants also shared how the PD enabled them to not only understand the science behind AdoptA-Stream but also how to implement sites on their school grounds, with one participant noting, "I think the biggest wow for me was learning more about the water quality testing with Adopt A Stream. Several years ago at my school, we got the stuff and attempted to do it, but I don't think we really knew what we were doing and understood what it was. It makes so much more sense about what we should have been doing, and we definitely were not doing things the right way. So it's nice to have the training and know what we're doing now".

\subsubsection{Principle B: Identity}

Identity development was discussed by all 19 participants in terms of how they saw themselves and others (lifelong learners/curious, love of nature) and how they viewed what they "were not" (not one who observes or identifies and/or not one who takes students outdoors) to what they saw themselves becoming (smart/comfortable, greater connection to watershed, and outdoor teacher). Questions from the teacher environmental literacy survey [50] also confirmed how participants viewed themselves prior to the PD and after the PD (Table 4).

Table 4. Teacher environmental literacy identity question pre/post-results.

\begin{tabular}{lcc}
\hline Statement & $\begin{array}{c}\text { Pre-Response Rate } \\
\text { Agree or Strongly Agree }\end{array}$ & $\begin{array}{c}\text { Post-Response Rate } \\
\text { Agree or Strongly Agree }\end{array}$ \\
\hline I feel confident in my ability to create a change in the environment. & $65 \%$ & $85 \%$ \\
\hline I am confident in my ability to work with others to create a change \\
to benefit the environment. & $80 \%$ & $100 \%$ \\
\hline I feel like I have a strong connection to the environment. & $85 \%$ & $95 \%$ \\
\hline I see myself as someone who cares for the environment in one or \\
more ways.
\end{tabular}

Over half of the participants shared how the whole group was motivated and committed to learning, as one participant stated, "There was not a single person in this whole group that was not motivated to be here, and once they were here, participated fully until there was just no more time left". This group-level identity was mentioned as helping participants fully engage and contribute. One participant noted that having this group of motivated colleagues felt like "almost a family environment". He shared, "I don't get to geek out with my friends over those things because they're not science people. I geeked out with a bunch of science teachers over something that most people would look at me like I was crazy for being excited about. A sundew. Most people won't even ever see one. And we're a group standing around staring at something the size of a dime, and we were actually excited to be doing it. And then we walked off and each found our own little packs, and we were all super excited to have found our own. And then we would all run over to the person that found their own. I mean, I love being outside. I love the critters. But every once in a while, you just get out in it and you get a renewed appreciation for it. And especially, if you go with people who share similar interests as you. And it's exciting to be a part of a group that's excited about this stuff". 
Participants described themselves in terms of how they saw themselves, what they were "not", and what they saw themselves becoming (Figure 4).

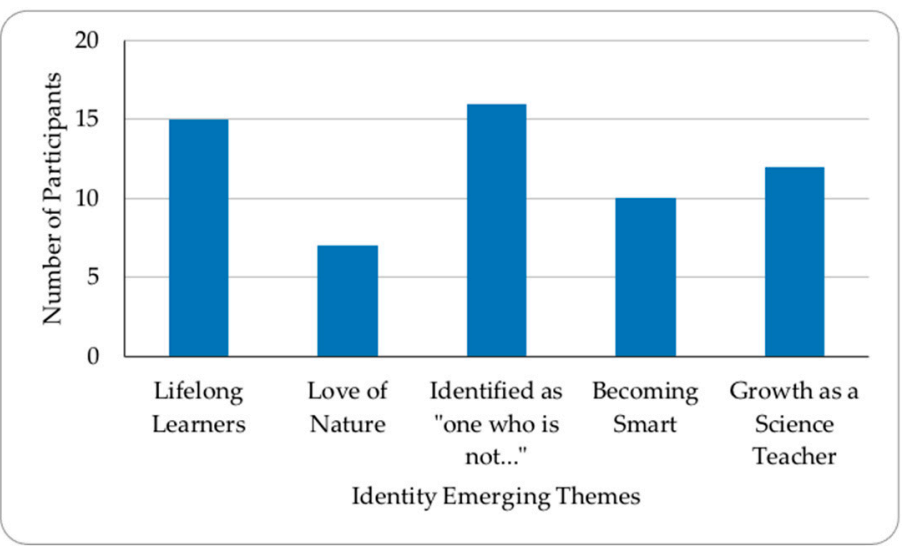

Figure 4. The frequency of emerging themes for the code identity.

One participant shared how "science is always going to start with being curious about something for me. If I'm not curious about it, I'm not learning it". Another described her cycle of learning that occurred, "And when I'm talking about that I'm learning, not only my learning from you [PD instructors] but I'm learning from others. I feel like I'm also contributing to that teachable moment. So I'm receiving those teachable moments and I feel like there are times that I can actually participate and give some of those teachable moments". In terms of love for nature, one participant stated, "I'm very motivated to help the environment. I'm a people person, and I really feel as though this workshop is going to help my ability to use science to help people not just to understand science, but to help them understand science and their impact and how they can better themselves in the whole process especially with the state of the world the way it is".

Participants also noted that participating in the PD highlighted what they were "not", with the two most common mentioned attributes being not one who observes or identifies and/or not one who takes students outdoors. Yet even in identifying what they were not prior to the PD, all participants who mentioned these also noted how their identity was now shifting and they were starting to become someone who observes and identifies and/or someone who is going to take their students outdoors. The theme of not being someone who can identify organisms to becoming someone who was able, comfortable, and excited to find and identify supported the knowledge theme of identification skills. As one participant shared, "I've learned characteristics, how to distinguish things. So that's something that I was like, "Oh, I can do this". It's becoming more and more natural".

Finally, participants also shared what they saw themselves becoming. Participants discussed feeling good or proud of themselves and connected these feelings to increases in knowledge, particularly in terms of identification and content. In terms of professional growth, a participant stated, "I'm really, really excited to go back and teach. It [next school year] just can't get here fast enough, even though we just got on summer break. But there's so much. I'm really, really excited to grow as a science teacher". Another participant stated, "It made me want to do more fieldwork. I'm going to be honest. I have enjoyed this. And being in the classroom, I've only been there 10 years, but even being in the classroom, I was kind of getting burned out with some of this. So being able to come back and kind of reignite my passion for science and what I like, too".

\subsubsection{Principle C: Place}

Place was also recognized as an important component of the PD (Figure 5). One participant summarized it as, "A lot of what I've experienced here is specific to the Okefenokee, but a lot can definitely be transferred to my area. So I'm excited to use my experience here to find kind of a similar eye opening experience for them when we go outside. Like I 
said, going out on the nature trail. Okay. But really digging, and finding those examples, and finding things for them to question and be really interested in". Another participant shared, "I came to the United States when I was 12. So I really do not know any history of our State or the United States, as a matter of fact. And I've heard things through my education, through college but I really have not had a lot of time to get to know where I live, the state where I live. So being able to be here and experience and go back home and tell my own kids of the experience, it's just a very different perspective on the history. I feel a lot more prepared to talk to my kids about watersheds, birds, to talk to my kids about trees, to talk to my kids about the swamp. It's a big difference from before I came".

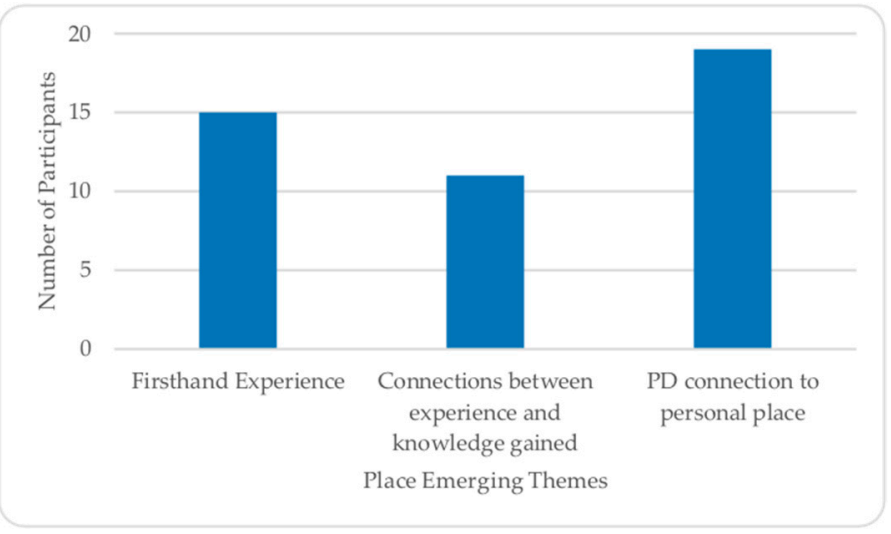

Figure 5. The frequency of emerging themes for the code place.

Participants also indicated that experiencing the Okefenokee first hand afforded them opportunities to make connections between their experiences and knowledge gained. As one participant connected first-hand observations she made with the water quality testing results, "I was watching these fish come to the surface gasping for air, and I thought, 'Well, that's odd. I don't know that I've ever noticed that before'. But I didn't say anything or ask anybody about or didn't point it out. I just noticed it and went on. And then, when we started actually doing the testing and realized how low the oxygen content was in the water, then I was able to connect that back to what I had seen". This participant went on to say, "And then it just got me thinking, that water is very different from the water that I'm going to be testing at my home site in moving water in the mountains. I know that it's going to be very different, but I'll be able connect that back and relate it back to our local watersheds".

In addition to pinpointing being in and experiencing the Okefenokee ecosystem, participants discussed their places and spaces in terms of knowing it better, understanding the environmental quality, and recognizing historical/cultural aspects that influence it. These indicate that participants were beginning to engage and develop their critical consciousness of place (42) as they were in the beginning stages of recognizing environmental issues and disruptions in their place (decolonization). For instance, one participant observed how she began to think about her local water quality, "I'm interested historically in going back. Especially during the 1970s because a lot was happening on the coast. And going back and really bringing that history in because I think that makes students relate to it from a historical perspective, but also just knowing more about the place and the harbor deepening and connecting it to environmental law". At the same time, participants started to re-imagine their places as areas where their students could become more invested in living responsibility within their watersheds (reinhabitation). As one participant commented, "So I'm really interested in doing some of this monitoring and learning about the water that's in our area. I want to help educate them [students] on the water that they're drinking that 'This is the water that you swim in. This is what you use to water your gardens. This is our water". 


\subsubsection{Principle D: Action}

The actions our participants shared centered around their roles as science teachers (Figure 6). As one participant stated, "I want to do more with, kind of, big picture down to small picture. I didn't really do that when I taught watersheds this past semester in environmental, and so I want to do more of looking at the state or even the country as a whole, and then zooming in smaller and smaller and smaller, talking about what are some potential problems we see in our watershed here but looking at it from this perspective. I want to do more visualization with the kids". Another participant shared that his goal was to use science to "maintain water as a resource" while another planned to use science to "help organisms in our watersheds".

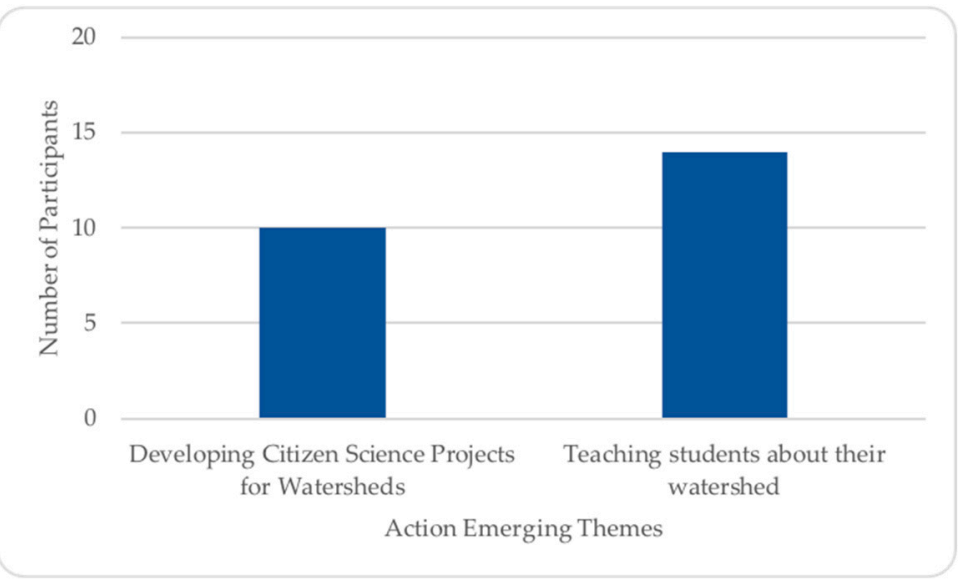

Figure 6. The frequency of emerging themes for the code action.

One participant compared her actions to planting seed, "So help others by putting in your little seed, whether it be by collecting trash, by learning the difference between $X$ and $\mathrm{Y}$ or so and so. So by informing my students with information that they need to pass a test or to become better citizens or for them to tell their family and friends about it, that's helping others". While another participant wanted to take action with his fellow teachers, "I want to connect with the ninth-grade environmental teacher. I want to connect with the high school biology teacher. I want to connect with the eighth grade for the physical science teacher. I mean we even share a closet. I can literally pop my head into her room at any given point. We do probably five times a week. I want to connect here to what I'm doing so the students have a more consistent understanding of how everything connects".

\subsubsection{Principle E: Vision}

In discussing their vision for a more just future for the environment, participants shared a common vision of the future that was two-fold: helping students grow into informed citizens and connecting their local community to science and the natural world (Figure 7). As one participant noted, "there's a missing community engagement in environmental science, and saying let's look in our community. We don't all have to look at a global scale or anything like that, but what's going on in our community? How can we address some of these things in our community that might not change on a global scale but it can impact on a smaller scale?".

As participants shared their visions, one participant noted, "As teachers, if we're going to get any type of community buy-in, we have to be able to discuss it. We have to be able to show how to use the tools, why the tools are important, how they can impact the local community, and why does it matter in the local community to be able to use science and to be able to engage". Another participant summarized his intent with, "My goal, as an educator, is to teach them well enough to where they go out and they teach others about it. And by teaching others, then we should be able to hopefully, in time improve our environment". 


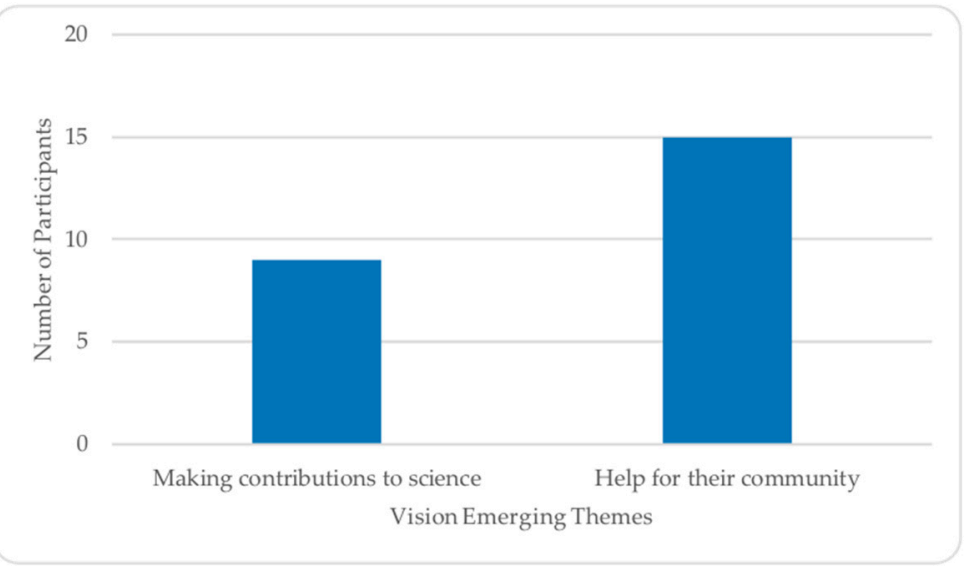

Figure 7. The frequency of emerging themes for the code vision.

Participants also agreed on how showing students that they could contribute to science would empower the students to envision themselves differently. For instance, one participant said, "If I can get them [students] to understand that they can contribute, I think it adds to their self-worth. And again that goal of becoming a citizen, being productive and conscious of what they're doing". Yet, another participant also shared, "And it gives you a feeling like you're part of it. And if you have a personal connection to a bigger whole, it keeps you motivated. It keeps you wanting to go back and do that. You don't have to be an environmental biologist or a chemist. You just have to want to understand. And once you understand it, you're not afraid of it. You can do it. You can collect our data, contribute, and feel a part of it".

\subsubsection{Summary of CEA Results}

In the co-occurrence analysis (Table 5), we also noted how principle a (knowledge) and principle $\mathrm{b}$ (identity) were frequently coded together $(n=43)$, which affirms the framework given developing knowledge/expertise directly influences identity development. Principle a (knowledge) and principle c (critical consciousness of place) also co-occurred most often together $(n=43)$; this again exemplifies the CEA framework as the environmental sciences in conjunction with historical and cultural knowledge directly impacts critical consciousness of place development. Finally, principle d (action) and principle e (vision) co-occurred together at the highest rate $(n=48)$. These two principles work hand in hand as indicating one's desire or ability to act enables one to envision opportunities for themselves and others to enact.

Table 5. Co-occurrence of CEA codes.

\begin{tabular}{cccccc}
\hline Codes & Action & Identity & Knowledge & Place & Vision \\
\hline Action & & 22 & 25 & 31 & 48 \\
Identity & 22 & & 43 & 16 & 21 \\
Knowledge & 25 & 43 & & 43 & 26 \\
Place & 31 & 16 & 43 & & 28 \\
Vision & 48 & 21 & 26 & 28 & 136 \\
Totals & 138 & 121 & 159 & 130 & \\
\hline
\end{tabular}

In analyzing the emergent themes for each code, three overarching themes surfaced. First, scientific knowledge as the foundation for our PD was instrumental in CEA development. Exposing teachers to the science research and content strengthened their knowledge and identity and helped them to become comfortable enough to take action and envision implementing citizen science with their students. Second, the place-based nature of our PD reinforced the importance not only the importance of the Okefenokee Swamp, as one of Georgia's most unique ecosystems, but also tethered local watersheds together throughout 
Georgia and helped participants see how their local areas came together in larger watersheds that eventually flowed to the Gulf of Mexico or Atlantic Ocean. Finally, the focus on Adopt-A-Stream as a community program enabled our participants to further connect to their students' lives as well as to themselves. This is the distinction between CEA development and CSA, in that place becomes of utmost importance, affording opportunities for a more vested committed as participants lived and worked in the impacted communities.

\subsection{Constraints}

Analysis of the data revealed an additional theme beyond the CEA principles-the constraints felt by participants that impacted their CEA development in some way (Figure 8).

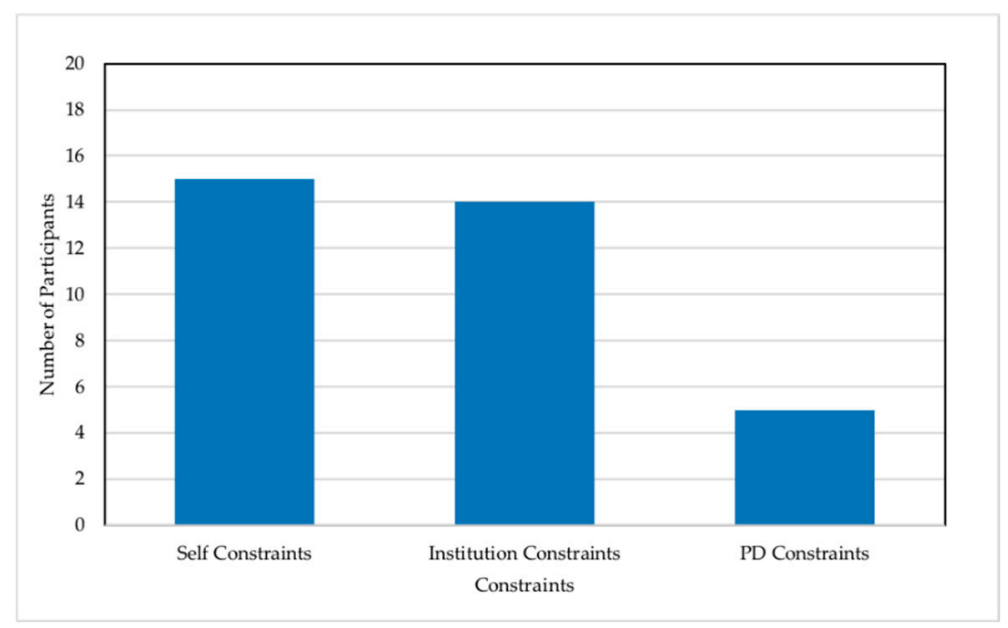

Figure 8. The frequency of emerging themes for the code constraints.

There were self-constraints described that pertained specifically to participant performance or engagement while at the PD. Their own lack of knowledge coming into the PD may have hindered their participation. They described situations where the PD provided new opportunities that differed from the way they had previously taught in their classroom; even interacted with fellow participants in a different way than their colleagues at home. Seven participants described situations where they had previously been teaching a certain way, some as a new teacher and some as veteran teachers, but had learned a different method through the PD. Many of the examples they provided included not taking students outside for field experiences, because of the complications that can arise in taking large classes outside. One described her personal reflection following a week of working outside in the swamp, "Why do I not do more of that with my students? Why are they not having those opportunities? And I think just the activities that we did are things that I don't typically do. I don't get outside very much".

Fifteen participants shared how a lack of content knowledge hindered their behavior or a personal awareness of a lack of knowledge. This subcategory included the largest number of participants, and many of the participants expressed multiple examples of lack of knowledge throughout the interview. "It took me longer"; "I couldn't figure it out"; "I've never been in a swamp". In trying to explain their shift in plans for their classroom, they usually had to start by saying why they could not teach something initially, which started with a lack of understanding or familiarity with some aspect of the swamp or watershed ecology. One participant even stated, "Asking questions in a group of people is really scary. Because I don't ever want to be seen as the dumb one".

There were also institutional constraints that participants identified and shared as possible barriers to implementing the actions and visions they had developed. Five participants expressed their frustration with colleagues from their schools not joining them for the summer PD or not being interested in trying something new or lack of willingness to change a current practice in their school. One participant who had mentioned how 
rejuvenated the PD made her feel going into the following year seemed downcast when she shared, "I'd be excited to show them what all I learned in the swamp. But I don't feel like it's going to be really encouraged". Some participants described situations in their classrooms that had previously impacted the way they taught or planned for instruction. Some even suggested that resistant colleagues missed out on this opportunity; perhaps this resistance would impact the shift in instruction upon return to the classroom.

Five participants shared that the responsibilities or workload expected in their school was too much to add something new to their plate. One participant explained that there had previously been another teacher at her school who had been leading some citizen science field work, but when that person left, "nobody stepped up to take that on. It's one of those things that nobody wants anything extra on top of what all they've already been doing". Another participant expressed teachers feel that there are expectations at the school level, perhaps from administrators, to adhere to a certain pacing guide or set of expectations that do not allow for a dramatic change in instructional practice. "We sometimes get pigeonholed trying to meet deadlines and standards, and this is just a revitalization of how important it is to step away from that".

Four participants shared concerns about the students in their local schools-concerned about their students' opportunities and awareness to engage in science and environmental education compared to peers in other areas throughout the state. These four participants all taught in schools with high poverty and worked with historically marginalized students in regard to access to science and environmental education. One shared her concern for student futures, "I think they are afraid even to express their opinion and I think if they don't work through fear, whatever they think would never be heard. And if your voice isn't heard you become frustrated and you limit yourself".

Finally, participants identified barriers within the PD implementation itself. Five participants shared that the amount of material that was planned for the week-long PD moved too quickly for them to adequately process. This led to missed information and, in some cases, frustration with the missed opportunity. One participant shared how during the chemistry lecture, she started to shut down: "Actually, I got kind of frustrated with it. I kept getting up and going to the bathroom and coming back because I was getting frustrated, but I'm the kind of person, when I get overwhelmed, I need a break, and then I will come back. But even though that happened during the chemistry unit, I think it was a good thing because it reminded me of what it's like to be a struggling student, because I had forgotten that feeling. In the moment, I was really frustrated, but now, reflecting on it, that was a good experience". Another clarified, "In the spring preview, we learned a lot, and it was just-it went over my head. So I just wanted to go into more and understand it better. And I feel with the actual experiences and with the lectures we had, it was more like, oh, it finally clicks, type of thing".

\section{Discussion}

Our study revealed that teachers did develop their CEA during a PD focused on local watershed investigations through water quality citizen science projects. CEA was enabled through multiple opportunities participants had to enact and take up the five principles. Throughout the PD, participants were able to deepen their understanding of watersheds through classroom activities, field experiences, and citizen science investigations. The water quality monitoring enabled engagement in the practices and modes of inquiry of environmental scientists (principle a: knowledge). Participants' identity development manifested throughout the PD as they recognized times when they knew content as well as accomplished what they thought they could not, such as learning to identify macroinvertebrates (principle b: identity). A place-based emphasis was central to the PD, as four out of the five days involved field investigations within the swamp. Participants readily made connections to these first-hand experiences, and all nineteen were able to transfer their understanding and curiosity to their own watershed and school grounds, which supported their deepening understanding of the places and spaces they 
occupy. This deepened understanding led to the budding of a critical consciousness of place (principle c: place), as they realized how their watersheds were impacted and began to consider ways they could educate others about how to appreciate and protect local waterways. This led to participants sharing actions they planned to take (principle d: action) in order to apply the expertise and awareness they had gained. These action steps fostered conversations and moved the participants toward thinking about and planning how to engage the communities in which their students lived, through imagining what they considered a more just world (principle e: vision) that involved them and their students learning how to help others understand and feel responsible for the health of their local watershed, ultimately leading to a more sustainable future. These findings confirm other citizen science research that found students and teachers were able to envision themselves as active participants who were capable of doing science $[15,43,54]$. In addition, the desire of participants to involve parents and community members aligns with the findings from environmental education research that explicit opportunities for home involvement need to be designed to increase general awareness [55].

Though each participant was able to engage and develop their CEA, there were times when CEA was constrained as participants struggled with their perceptions of their schools, themselves, and the PD. Though participants acknowledged the value of the high-level science content of the PD, they had at times struggled to keep up or often felt that they could not adequately process the content. This point of view surfaced most often during the water chemistry and macroinvertebrate lectures. Some participants also struggled with how they saw themselves, positioning themselves as not "one who identifies organisms", teetering on whether they recognized themselves as having expertise or not. Yet, many of the identified constraints were also opportunities for participants to voice a justification for a former action and then a personal reflection on how their actions had shifted due to participation in this PD. However, this is not uncommon to identity work, as science identities are not fixed, static identities but rather are fluid and malleable over time [56].

Much like identity development, CEA is not concrete; rather, it is fluid, providing an ebb and flow, at times even appearing to backtrack or lessen depending on one's situation. Thus, teachers need repeated exposure to PD in order to fully cultivate CEA, which aligns with best practices for effective teacher PD [57]. In addition, providing PD that is situated in both experiential and active learning situations and focused on watershed ecology and water quality citizen science projects has the potential to transform classrooms as teachers engage students in long-term schoolyard-monitoring projects [54,58]. Thus, teachers can use the citizen science projects they implement to increase their students' engagement within their local watersheds [59] and to afford opportunities for students' CEA and environmental literacy development.

The scope of this study was limited to one PD program focused on watersheds and citizen science water quality monitoring through Adopt-A-Stream. The participants chose to be a part of the program; thus, they self-selected in the sense that they chose to apply for the PD. The duration of the program was short (one week), although it was a typical length for an overnight PD. Yet, the insights gained from this study are informative in regard to teachers' CEA development.

\section{Implications}

This research informs the field's understanding of how teachers engage in EE and strengthen their CEA, thus enabling scientific and environmental literacy development. Considering NAAEE's [44] four principles of environmental literacy, our study found that participants were able to deepen their environmental literacy. First, participants deepened their knowledge and understanding of EE through explorations of natural areas and citizen science water quality monitoring. Second, participants developed empathic dispositions toward their watersheds, felt a personal responsibility for taking care of them, and were motivated to educate others. Third, participants deepened their cognitive abilities by learning about and engaging in scientific practices, as well as deepened their understanding 
about and connections to local places. Finally, participants indicated that they wanted to be more aware of environmental concerns in their community and considered actions to address concerns discovered. Participants also developed critical literacy skills of questioning, synthesizing, and visualizing [60]. Participants generated questions about their local watersheds, synthesized and transferred the knowledge they gained, and visualized a more sustainable future as well as a renewed sense of passion and commitment to environmental education.

Science identity development is a fairly new area of study for citizen science research [61]; however, the few studies conducted have tended to focus on student science identity development $[43,56]$ while engaged in citizen science activities and not on teachers' identities. We are not attempting to make claims that participants' CEA development was cemented or had long-lasting effects, as our study only provides a brief snapshot of time, as CEA, much like one's identity, is fluid and malleable over time [62,63]; thus, CEA is continually being shaped and reshaped. However, participants' meanings of the experience indicated that their thinking about their watershed and community had changed, so the question then becomes about how enduring this change might be. Further exploration of teachers' identity work through longitudinal studies will move the field forward in understanding how identity and agency can work together to produce stable and predictable increases in awareness of local environmental issues surrounding watersheds. By better understanding how teachers engage with their local watersheds and come to recognize themselves as environmentally aware people, equitable environmental learning spaces can be constructed.

Author Contributions: Conceptualization, L.D.H.; methodology, L.D.H. and H.C.S.; software, L.D.H. and H.C.S.; validation, L.D.H. and H.C.S.; formal analysis, L.D.H. and H.C.S.; resources, L.D.H. and H.C.S.; data curation, L.D.H. and H.C.S.; writing-original draft preparation, L.D.H. and H.C.S.; writing-review and editing, L.D.H. and H.C.S.; visualization, L.D.H. and H.C.S.; project administration, L.D.H. and H.C.S.; funding acquisition, L.D.H. and H.C.S. All authors have read and agreed to the published version of the manuscript.

Funding: Research reported in this publication was supported by the Gulf Research Program of the National Academies of Sciences, Engineering, and Medicine under the Grant Agreement number 2000009821. The content is solely the responsibility of the authors and does not necessarily represent the official views of the Gulf Research Program or the National Academies of Sciences, Engineering, and Medicine.

Institutional Review Board Statement: The study was conducted according to the guidelines of the Declaration of Helsinki, and approved by the Institutional Review Board of Georgia Southern University (protocol code H19045 and 10/5/2018).

Informed Consent Statement: Informed consent was obtained from all subjects involved in the study.

Acknowledgments: We would like to acknowledge Checo Colon-Gaud, Shainaz Landge, Kania Greer, and Mary Thaler for their support in developing and implementing the Our ${ }^{2}$ Swamp curriculum and PD.

Conflicts of Interest: The authors declare no conflict of interest.

\section{References}

1. Moreno-Guerrero, A.J.; Romero-Rodríguez, J.-M.; López-Belmonte, J.; Alonso-García, S. Flipped learning approach as educational innovation in water literacy. Water 2020, 12, 574. [CrossRef]

2. Sozcu, U.; Ürker, A. Examining the water literacy levels of high school students according to some variables. Asian J. Educ. Train. 2020, 6, 569-582. [CrossRef]

3. Vitousek, P.M.; Mooney, H.A.; Lubchenco, J.; Melillo, J.M. Human domination of earth's ecosystems. Science 1997, $277,494-499$. [CrossRef]

4. Grimm, N.B.; Faeth, S.H.; Golubiewski, N.E.; Redman, C.L.; Wu, J.; Bai, X.; Briggs, J.M. Global change and the ecology of cities. Science 2008, 319, 756-760. [CrossRef] [PubMed] 
5. Calabrese Barton, A.; Tan, E. Where da heat go? Developing critical science agency through student-directed science documentaries on urban heat islands. In Proceedings of the Annual Meeting of the American Educational Research Association, New York, NY, USA, 24-28 March 2008.

6. Taylor, D.E. Race, Class, Gender, and American Environmentalism; USDA: Portland, OR, USA, 2002.

7. Amahmid, O.; El Guamri, Y.; Yazidi, M.; Razoki, B.; Rassou, K.K.; Rakibi, Y.; Kniki, G.; El Ouardi, T. Water education in school curricula: Impact on children knowledge, attitudes and behaviours towards water use. Int. Res. Geogr. Environ. Educ. 2019, 28, 178-193. [CrossRef]

8. Calabrese Barton, A.; Tan, E. Funds of knowledge and discourses and hybrid space. J. Res. Sci. Teach. 2009, 46, 50-73. [CrossRef]

9. Barnett, M.; Lord, C.; Strauss, E.; Rosca, C.; Langford, H.; Chavez, D.; Deni, L. Using the urban environment to engage youths in urban ecology field studies. J. Environ. Educ. 2006, 37, 3-11. [CrossRef]

10. Calabrese Barton, A.; Tan, E. We be burnin'! Agency, identity, and science learning. J. Learn. Sci. 2010, 19, 187-229. [CrossRef]

11. Wheaton, M.; Ash, D. Exploring middle school girls' ideas about science at a bilingual marine science camp. J. Muse. Educ. 2008, 33, 131-142. [CrossRef]

12. Tan, E.; Calabrese Barton, A.; Turner, E.; Gutiérrez, M.V. Empowering Science and Mathematics Education in Urban Schools; Tan, E., Barton, A., Turner, E., Eds.; The University of Chicago Press: Chicago, IL, USA, 2012.

13. Brown, B.A.; Reveles, J.M.; Kelly, G.J. Scientific literacy and discursive identity: A theoretical framework for understanding science learning. Sci. Educ. 2005, 89, 779-802. [CrossRef]

14. Roberts, D.A. Scientific literacy/Science literacy. In Handbook of Research on Science Education; Lawrence Erlbaum Associates: Hillsdale, NJ, USA, 2007; pp. 729-780.

15. Jordan, R.C.; Ballard, H.L.; Phillips, T.B. Key issues and new approaches for evaluating citizen-science learning outcomes. Front. Ecol. Environ. 2012, 10, 307-309. [CrossRef]

16. National Academies of Sciences, Engineering, and Medicine. Learning through Citizen Science: Enhancing Opportunities by Design; National Academies Press: Washington, DC, USA, 2018.

17. Hiller, S.E.; Kitsantas, A. Fostering student metacognition and motivation in STEM through citizen science programs. In Metacognition: Fundaments, Applications, and Trends. Intelligent Systems Reference Library, Vol 76; Peña-Ayala, A., Ed.; Springer: Cham, Switzerland, 2015.

18. Huffling, L.D.; Scott, H.C.; Collins, R.; Gantt, B.; Johnson, H.; Weeks, M. Science educators' perspectives on learning to utilize citizen science in our teaching. In Enhancing Stem Motivation through Citizen Science Programs; Hiller, S.E., Ed.; Nova Science Publishing Inc.: Hauppauge, NY, USA, 2019.

19. Bonney, R.; Cooper, C.B.; Dickinson, J.; Kelling, S.; Phillips, T.; Rosenberg, K.V.; Shirk, J. Citizen science: A developing tool for expanding science knowledge and scientific literacy. BioScience 2009, 59, 977-984. [CrossRef]

20. Tan, E.; Calabrese Barton, A. Unpacking science for all through the lens of identities-in-practice: The stories of Amelia and Ginny. Cult. Stud. Sci. Educ. 2008, 3, 43-71. [CrossRef]

21. Basu, S.J.; Calabrese Barton, A.; Clairmont, N.; Locke, D. Developing a framework for critical science agency through case study in a conceptual physics context. Cult. Stud. Sci. Educ. 2009, 4, 345-371. [CrossRef]

22. Tsurusaki, B.K.; Calabrese Barton, A.; Tan, E.; Koch, P.; Contento, I.R. Using transformative boundary objects to create critical engagement in science: A case study. Sci. Educ. 2013, 97, 1-31. [CrossRef]

23. McNeill, K.L.; Vaughn, M.H. Urban high school students' critical science agency: Conceptual understandings and environmental actions around climate change. Res. Sci. Educ. 2012, 42, 373-399. [CrossRef]

24. Endreny, A.H. Urban 5th Graders conceptions during a place-based inquiry unit on watersheds. J. Res. Sci. Tea 2010, 47, 501-517. [CrossRef]

25. Lutts, R.H. Place, home, and story in environmental education. J. Environ. Educ. 1985, 17, 37-41. [CrossRef]

26. Place-based Education Evaluation Collaborative. The Benefits of Place-Based Education: A Report from the Place-Based Education Evaluation Collaborative, 2nd ed.; PEEC: Bennington, NH, USA, 2010.

27. Barnett, M.; Vaughn, M.H.; Strauss, E. Urban environmental education: Leveraging technology and ecology to engage students in studying the environment. Int. Res. Geogr. Environ. Educ. 2011, 20, 37-41. [CrossRef]

28. Bates, K.; Teudt, M.; Collier, J. Mapping points for a place-based pedagogy of practice. Curric. Perspect. 2019, 39, 91-96. [CrossRef]

29. Sukhontapatipak, C.; Srikosamatara, S. The role of field exercises in ecological learning and values education: Action research on the use of campus wetlands. J. Biol. Educ. 2012, 46, 37-41. [CrossRef]

30. Carter, R.L.; Simmons, B. The history and philosophy of environmental education. In The Inclusion of Environmental Education in Science Teacher Education; Bodzin, A.M., Shiner Klein, B., Weaver, S., Eds.; Springer: Dordrecht, The Netherlands, 2010 ; pp. 3-16. [CrossRef]

31. Roth, C.E. Environmental Literacy: Its Roots, Evolution, and Directions in 1990s; U.S. Department of Education: Columbus, OH, USA, 1992.

32. Iozzi, L. A Summary of Research in Environmental Education, 1971-1982. The Second Report of the National Commission on Environmental Education. Monographs in Environmental Education and Environmental Studies, Volume II; Eric Clearinghouse: Columbus, $\mathrm{OH}$ USA, 1984. 
33. McBeth, W.; Hungerford, H.R.; Marcinkowski, T.; Volk, T.L.; Cifranick, K. National Environmental Literacy Assessment, Phase Two: Measuring the Effectiveness of North American Environmental Education Programs with Respect to the Parameters of Environmental Literacy, Final Research Report; NOAA: Carbondale, IL, USA, 2011.

34. McBeth, W.; Volk, T.L. The national environmental literacy project: A baseline study of middle grade students in the United States. J. Environ. Educ. 2010, 41, 55-67. [CrossRef]

35. Rickinson, M. Learners and learning in environmental education: A critical review of the evidence. Environ. Educ. Res. 2001, 7, 37-41. [CrossRef]

36. Coyle, K. Environmental Literacy in America: What Ten Years of Neetf/Roper Research and Related Studies Say about Environmental Literacy in the U.S.; The National Environmental Education and Training Foundation: Washington, DC, USA, 2005.

37. Marcinkowski, T. Using a logic model to review and analyze an environmental education program. In NAAEE Monograph Series, Volume 1; Volk, T.L., Ed.; NAAEE: Washington, DC, USA, 2004.

38. Schusler, T.M.; Krasny, M.E. Environmental action as context for youth development. J. Environ. Educ. 2010, 41, 208-223. [CrossRef]

39. Tomasek, T.; Huffling, L.D.; Matthews, C.E.; Carlone, H. Unlikely partners: The voucher specimen project \& science service learning. In Service and Service Learning; Newman, J.L., Sunal, D.W., Sunal, C.S., Eds.; Information Age Publishing: Charlotte, NC, USA, 2016; pp. 125-145.

40. Volk, T.L.; McBeth, W. Environmental Literacy in the United States; North American Association for Environmental Education: Washington, DC, USA, 1997.

41. Zelezny, L.C. Educational interventions that improve environmental behaviors: A meta-analysis. J. Environ. Educ. 1999, 31, 5-14. [CrossRef]

42. Greenwood, D.A. A critical theory of place-conscious education. In International Handbook of Research on Environmental Education; Stevenson, R., Brody, M., Dillon, J., Wals, A., Eds.; Routledge: New York, NY, USA, 2012; pp. 83-100.

43. Huffling, L.D. Critical Environmental Agency in a Field Ecology Program; University of North Carolina at Greensboro: Greensboro, NC, USA, 2015.

44. North American Association for Environmental Education. Developing a Framework for Assessing Environmental Literacy; NAAEE: Washington, DC, USA, 2011.

45. Glesne, C. Becoming Qualitative Researchers: An Introduction. Becoming Qualitative Researchers: An Introduction, 4th ed.; Pearson: Boston, MA, USA, 2011.

46. Phillips, D.; Noddings, N.; Lincoln, Y.S.; Bochner, A.P.; Barone, T.; Harry, B.; Stone, L. Nine perspectives of research. In Introduction to the Philosophies of Research and Criticism in Education and the Social Sciences; Paul, J.L., Ed.; Pearson: Upper Saddle River, NJ, USA, 2005; pp. 49-91.

47. Lichtman, M. Qualitative Research in Education: A User's Guide, 2nd ed.; Sage: Washington, DC, USA, 2010.

48. Strack, R.W.; Magill, C.; Mcdonagh, K. Engaging youth through photovoice. Heal. Promot. Pr. 2004, 5, 49-58. [CrossRef]

49. Wang, C.C.; Burris, M.A. Empowerment through Photo Novella: Portraits of Participation. Heal. Educ. Q. 1994, 21, 171-186. [CrossRef]

50. Hunter, R. Educator Environmental Literacy: A Mixed-Methods Study of Behavior, Identity, and Practices; Rutgers University: News Brunswick, NJ, USA, 2019.

51. Leech, N.L.; Onwuegbuzie, A.J. A typology of mixed methods research designs. Qual. Quant. 2007, 43, 265-275. [CrossRef]

52. Tracy, S.J. Qualitative quality: Eight "big-tent" criteria for excellent qualitative research. Qual. Inq. 2010, 16, 837-851. [CrossRef]

53. Miles, M.B.; Huberman, A.M. Qualitative Data Analysis: A Methods Sourcebook, 3rd ed.; SAGE Publishers: Thousand Oaks, CA, USA, 2014.

54. Ballard, H.L.; Dixon, G.H.; Harris, E.M. Youth-focused citizen science: Examining the role of environmental science learning and agency for conservation. Biol. Conserv. 2017, 208, 65-75. [CrossRef]

55. Mitchell, I.K.; Ling, C.; Krusekopf, C.; Kerr, S. Pathways toward whole community transformation: A case study on the role of school engagement and environmental education. Environ. Dev. Sustain. 2015, 17, 279-298. [CrossRef]

56. Carlone, H.B.; Huffling, L.D.; Tomasek, T.; Hegedus, T.A.; Matthews, C.E.; Allen, M.; Ash, M.C. Unthinkable selves: Identity boundary work in a summer field ecology enrichment program for diverse youth. Int. J. Sci. Educ. 2015, 37, 1524-1546. [CrossRef]

57. Darling-Hammond, L.; Hyler, M.E.; Gardner, M. Effective Teacher Professional Development; Learning Policy Institute: Palo Alto, CA, USA, 2017.

58. Dean, A.J.; Church, E.K.; Loder, J.; Fielding, K.S.; Wilson, K.A. How do marine and coastal citizen science experiences foster environmental engagement? J. Environ. Manag. 2018, 213, 409-416. [CrossRef] [PubMed]

59. Mitchell, N.; Triska, M.; Liberatore, A.; Ashcroft, L.; Weatherill, R.; Longnecker, N. Benefits and challenges of incorporating citizen science into university education. PLoS ONE 2017, 12, e0186285. [CrossRef] [PubMed]

60. Chambers, J.M.; Radbourne, C.L. Using the environment as text. Lang. Lit. 2015, 17, 1-20. [CrossRef]

61. Ballard, H.L.; Harris, E.M.; Dixon, C.G. Science Identity and Agency in Community and Citizen Science: Evidence E Potential; Commissioned paper for the Committee on Designing Citizen Science to Support Science Learning; National Academies Press: Washington, DC, USA, 2018.

62. Gee, J.P. Identity as an analytic lens for research in education. Rev. Res. Educ. 2001, 25, 99-125. [CrossRef]

63. Wenger, E. Communities of Practice: Learning, Meaning, and Identity; Cambridge University Press: New York, NY, USA, 1998. 